\title{
軟 鋼の交流による電解研磨についで
}

田 中 晃**

Akira Tanaka: On the Electrolytic Polishing of Mild Steel by Alternating Current. Some experiments on the electrolytic polishing of mild steel by alternating current (100 volts, 50cycles) were performed ito obtain the mirror-like surfaces and also the losses of weight due to the polishing and the irregularities of the polished surfaces were compared with the case of the polishing by direct current. In this experiment, the mixed solution of 90 per cent by voleume of phosphoric acid of Sp. gr. 1.75 and 10 per cent by volume of sulphuric acid of Sp. gr. 1.84 was mainly used as the electrolyte, and the carbon plate was used as the opposite pole.

The results of this experiments are summarized as follows: (1) It appears possible that the, surfaces of mild steels are polished by alternating current only below the solution temperature of $60^{\circ}$ and the best polished surface is obtained under the condition which is the current density of about $200 \mathrm{Amp} / \mathrm{dm}$ steel surface, and the solution temperature of $45^{\circ}$ (2) There are no 
appreciable differences in the microscopic appearances of the both surfaces which are polished by alternating current and by direct current. However, the polished surfaces by direct carrent show a tendency to increase the surface pitting. To avoid the surface pitting, it is effective to have the iron ions in the electrolyte about $1.5 \mathrm{~g} / \mathrm{L}$. (3) Although the loss of weight due to the polishing by alternating current is greater than by direct current, the surfaces by the latter are flat and highly polished. There fore, it seem that the projecting parts of the steel surface are more selectively soluble in the case of direct current than in the other case.

(Received Beptember 18, 1951)

\section{I. 粒}

電解研境生特殊溶液中において被研磨金属を陽趣として 研磨をなす方泆であるが, 1935 年に佛國の P. A. Jacquet に上つて發見せら机て以來急速な進步を逐げた。その後或 る種の金屬および合金については電源として交流をも利用 出來ることが制明した．これには日根氏の極板の表面生成 物の整洼作用による方法，およで純然たる交流による方法 があり，前者は原理的には牛波整流に上る直流研磨である と思われる，交流による電㺟研磨は直流の場合に比し電源 が容易人得られるという利點がある．鋼の交流に上る電解 研磨は田島博士によつて發見(1)せられ，工業的にも一部に 称用せられているが，その報告は比較的少く，かつ利用に ついてはな扔多くの問題があるように思われる。よつて著 者は東京工業大學精密機械研究所においてて田中萁博士の御 嗳助と御指導によつて，交流による軟鋼の電解研磨試驗を 行い，值流を用いた場合と比較捈討した

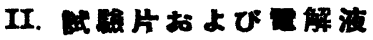

試版としては市眽の 僌鋼板を用い,これを長さ50 $\mathrm{mm}$ ， 巾 $10 \mathrm{~mm}$ ，厚さ $0.5 \mathrm{~mm}$ の片狀とし，何れも表面 をエメリー紙 02 まで仕上げた. 電解液としては $\mathrm{H}_{3} \mathrm{PO}_{4}$ (此重 1.75) $90 \% \mathrm{H}_{2} \mathrm{SO}_{4}$ (比重 1.84 ) $10 \%$ (容積\%)の 混合溶液を用いたが，別に $\mathrm{H}_{3} \mathrm{PO}_{4}$ (此重 1.75) 溶液につ いても若干の試驗を行つた. 本報告中特にことわりのない 限り $\mathrm{H}_{2} \mathrm{SO}_{4} 10 \%$ を含む溶液による結果である．この液は

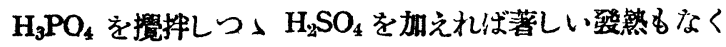
たら゙ちに使用に供することが出來，かつ相當の長特間にわ たつて使用出来る．た心゙し後述の如く研磨面は多くの電解 研磨液と同じく若干の鐵イオンが存在する方がよい結果を 万る.

\section{III. 試 留}

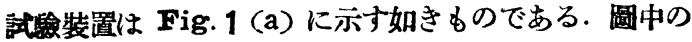
番號及記號恃(1)試驗片，(2)對極 (炭素板)，(3)電解液，(1)溫

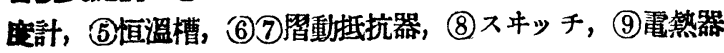
(V)電盾計，電流計である.

試驗片は對極と約 $40 \mathrm{~mm}$ 隔て〉本行垂直に設置し, 研 磨面積を $10 \times 10 \mathrm{~mm}^{2}$ とし, 液中に浸る他つ部分をラッ

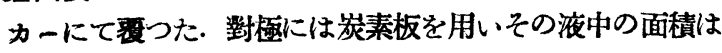
片面約 $40 \times 50 \mathrm{~mm}^{2}$ である.

直流を用いた場合の試驗は Fig.1 (b) の如きセレンに 上る整流回路にて全波整流を行い，これと並列に電池を接

（1）田島，電氣化學，14 (1946), 18.

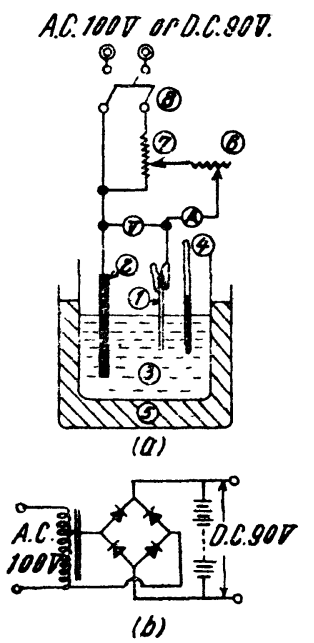

Fig. 1
綪した・交流電源としては 100 V 50の電嬁線を用いこ れを直接電源とした。

\section{IV. 䟛果}

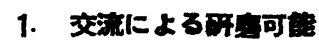

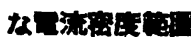

以上の試驗装置において 液を㩭挷せずに徐々に試㹂 片の交流㝬度を上昇せしめ た場合，電流一電筑曲線儿 水平部が現われる、すなわ ち笔流密度が坦加しないに もかわわらナ電郎の急激な 上乐が証められる。これが 電解液の溫度によつて著し

く糹化することを認めたので，各種の溫度に對する同閶俰 を澌定した結果は Fig. 2 の如くである.

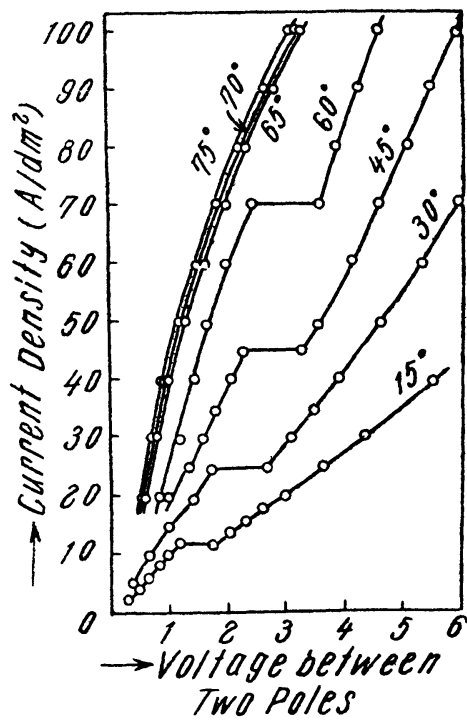

Fig. 2

圖は $15^{\circ}, 30^{\circ}, 45^{\circ}, 60^{\circ}, 65^{\circ}, 70^{\circ}$ 呿よび $75^{\circ}$ に對する電

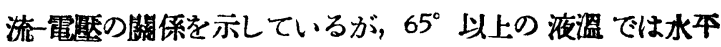
部分は現われない，その他の曲線つ水平部分は研磨電流㴦 度の下限を示するのであつて，それぞれ $15^{\circ} て ゙ 12 \mathrm{~A} /$ $\mathrm{dm}^{2}, 30^{\circ}$ で $25 \mathrm{~A} / \mathrm{dm}^{2}, 45^{\circ}$ で $45 \mathrm{~A} / \mathrm{dm}^{2}, 60^{\circ}$ にて $70 \mathrm{~A} /$ $\mathrm{dm}^{2}$ であり，これ以上の電流蜜においては盛んにガス

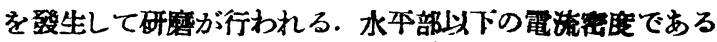


そ研磨されず表面は黑色の被膜で覆われ，ガスか㳔著して いる.これは後述の理由で水素カスであると思われる．研 磨域の上限は明膫に認められないが，餘り高電流密度であ ると面力䐠れるので， $300 \mathrm{~A} / \mathrm{dm}^{2}$ 程度以下が適當と思われ る.

$65^{\circ}$ 以上の液溫に特いては試驗片を液中に浸したのみ ですなわち無電流にても盛んにガスを發生し，研磨は相 當の高電流密度の場合であつても行われなかつた。この温 度は純化學的溶解加起る 61 62 $62^{\circ}$ 以上に相當する。 $\mathrm{H}_{33}$ $\mathrm{PO}_{4}$ (比重 1.75 )に對与る同樣の電流一電筑の關俰俚 Fig. の如くである.

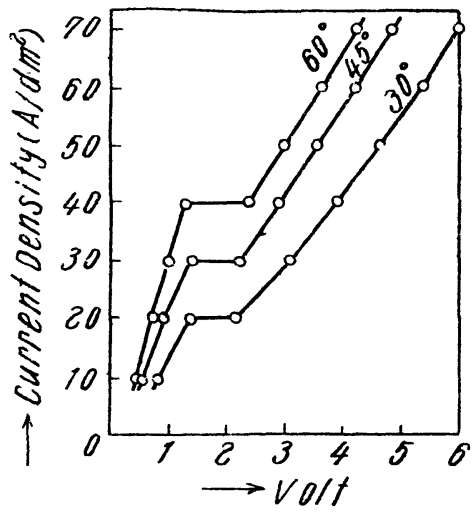

Fig. 3

\section{2. 淄 解}

交流による電解研磨においては試驗片力陽極となつた暚 間にの久溶解か起ると考えられるので，溶解量を測定し て，值流水よる場合と比較したままう液溫により可成り溶

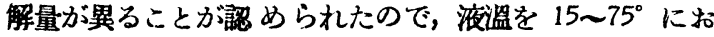
いて $15^{\circ}$ 置きに一定とし，䉓流密度をそれでれ $1 \mathrm{~A} / \mathrm{cm}^{2}$ ， $2 \mathrm{~A} / \mathrm{cm}^{2}, 3 \mathrm{~A} / \mathrm{cm}^{2}$ の 3 種につき試驗を行つた。時間は餘 り短いと稀量による誤差が導入されるし，また長い場合に 。は殊に高電流密度の場合に液溫の綡化が起るので，5 分間 とし，研磨の前後における試驗片の重量を化學天程にて种 量し，その差を以て溶解量とした．その測定結果を Fig.4 に示した．圖中 I, II, III はそれでれ交流による1 A $/ \mathrm{cm}^{2}$, $2 \mathrm{~A} / \mathrm{cm}^{2}, 3 \mathrm{~A} / \mathrm{cm}^{2}$ に對する溶解量であり， I'， II'， $\mathrm{III}^{\prime}$ は それぞれ直流 $1 \mathrm{~A} / \mathrm{cm}^{2}, 2 \mathrm{~A} / \mathrm{cm}^{2}, 3 \mathrm{~A} / \mathrm{cm}^{2}$ に對寸る溶解
交流においては，溶释に與かるのは平均值流電流であるか ら通電した電氣量つ本分をさらに波形交で割つた值が溶解 に關與する．オッシログラフによつて電流波形を驗するに

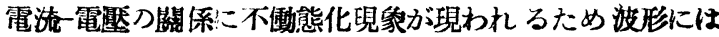
不儌態現象は見られず正弦波形となる，從つて等しい電 によつて直流拈よび交流で電晍すれば交流の場合には直 流の場合の $1 / 2 \times 1 / 1.11$ の電氣量によつて溶晖が起るこ ととなるにも拘らずなお若干多い溶浑量を示すことは Fig. 4 に見られる通りでちる。

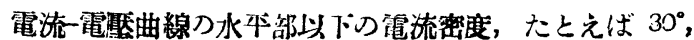
$45^{\circ}$ のそれぞれ $0.2 \mathrm{~A} / \mathrm{cm}^{2}$ の電流密度にて電解するに

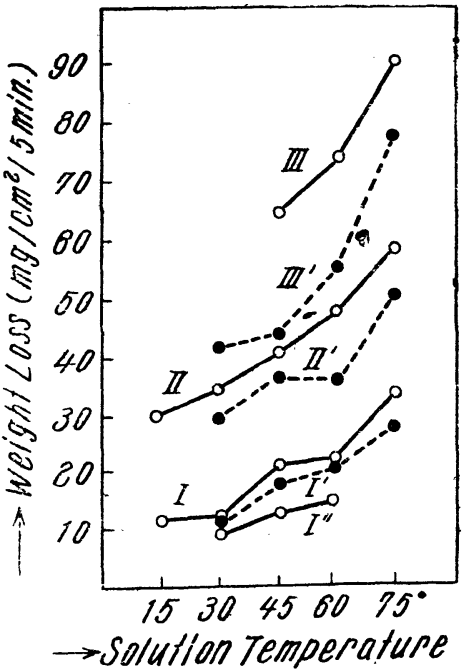

Fig. 4

$1 \mathrm{~cm}^{2}$ につき 5 分間にそれでれ $7.8 \mathrm{mg}$ また $60^{\circ}, 0.5 \mathrm{~A}$ では同一面積，同一特間に $19.5 \mathrm{mg}$ の溶解量成測定され た.これ等の數値はそれぞれの平均值流電流によつて鍄が 2 價のイオンとして溶出し，かつ $100 \%$ の電流效率を示 している.鐵は還元性ガス中においては 2 價として反㷳す るからこの時表面に附着しているガスは水素ガスであると 思われる。

\section{3. 研窝面の牀䁅}

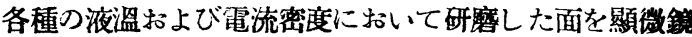
呿よび表面憸查㙨によつて調べた結果は次の如くである。

研磨面の顯微鏡寫筫をPhoto. 1 及び Photo. 2に示した.

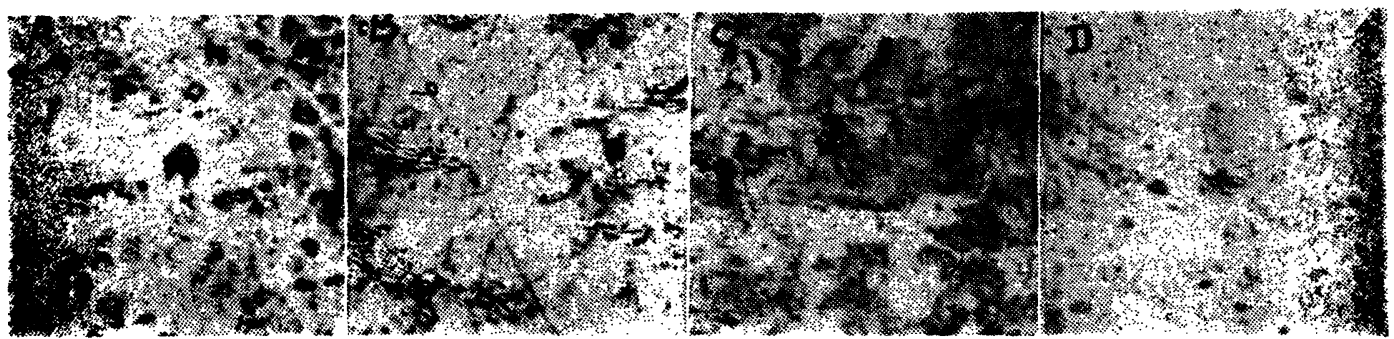

Photo. 1

量である.な呿 $\mathrm{I}^{\prime \prime}$ は交流を用い，電解液 として $\mathrm{H}_{3} \mathrm{PO}_{4}$

（比重 1.75）を用いた場合 $1 \mathrm{~A} / \mathrm{cm}^{2}$ に對する溶解量で 荒る。この結果によると，同一組成の液で電解した場合，
Photo. 1 は交流電解によるもので Aは $30^{\circ} 2 \mathrm{~A} / \mathrm{cm}^{2} 30 \mathrm{sec}$ B は $45^{\circ} 1 \mathrm{~A} / \mathrm{cm}^{2} 1 \mathrm{~min}, \mathrm{C}$ は $45^{\circ} 2 \mathrm{~A} / 30 \mathrm{sec}, \mathrm{D}$ は $45^{\circ}$ $2 \mathrm{~A} / \mathrm{cm}^{2} 15 \mathrm{sec}$ それぞれ研磨したもので著しい䙪化は認め 
られないが D は肉腿による觀察によれば未だ光輝面とは ならず研磨持間が不足である。また著者の 經驗によれば

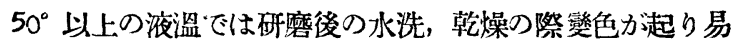

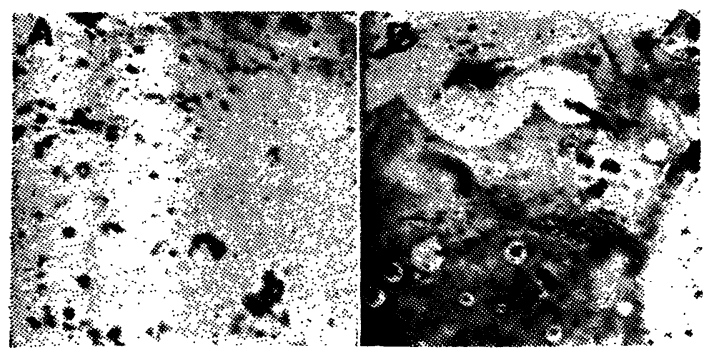

Photo. 2

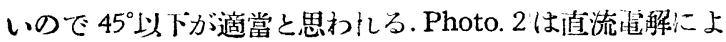
るものでA は $30^{\circ} 2 \mathrm{~A} / \mathrm{cm}^{2} 30 \mathrm{sec}, \mathrm{B}$ は $45^{\circ} 2 \mathrm{~A} / \mathrm{cm}^{2} 30 \mathrm{sec}$ の研磨面で B は特心變色が甚だしい，顯微鏡による觀察 の結果は交流打よび直流で特心變化はないが，直流電解の 方が pitting が起り易い. pittingは艾流では起り難く， 起つたとしても直流つ場合に比し小さいのが常である. pitting に關しては液中に持ける鐵イオンが非常に關係す る.この試驗においては鐵が約 $1.5 \mathrm{~g} / \mathrm{L}$ 溶解した場合に は餘り起らなくなつた。舄頁つ試料は電解液中に鐵イオン が約 $1.5 \mathrm{~g} / \mathrm{L}$ 溶解している時研磨したものである. 直流 電解によるPhoto.2A に敃いては明らかに多くの pit が認 められるしまた B においても同樣のことが認められる。

上記の試驗片の表面度日本光學製觸针式表面檢查㙨に上 つて試驗した結果はPhoto.3の如くである.A〜DはPhoto. 1A〜D に相當するもので，E 括よび $\mathrm{F}$ はPhoto. 2, A お よび B にそれれぞれ相當するものである。これらの寫傎は 何孔も水本方向に 50 倍，垂直方向に 500 倍の倍率で示 されている.この結果によると直流笔解心よる面はほとん ど本滑であるが，艾流によるものは未だェメリー紙に上る 凹凸が残つているものと思わ虬る。しかし交流によるもの は直流に上るもの上り溶解量は多いのであるから，結局交
流の場合には面流による電解研磨の機構として䐂められて いる凸部の選擇溶出力淔流の場合程顯著に行われないるの と思われる。

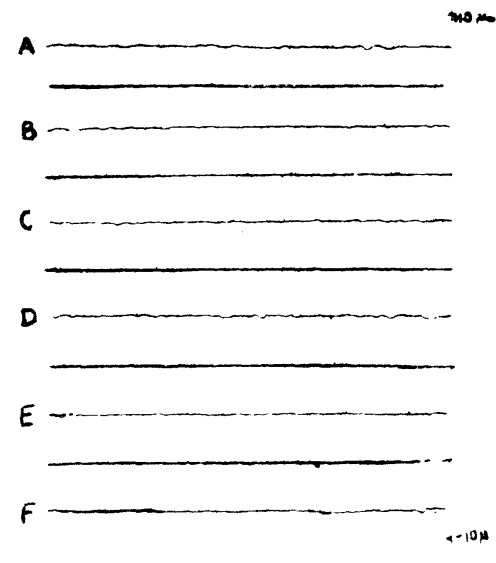

Photo. 3

\section{V. 結霄}

以上の結論として軟鋼の $\mathrm{H}_{3} \mathrm{PO}_{4}-10 \% \mathrm{H}_{2} \mathrm{SO}_{4}$ 溶液によ る交流を用いた電解研碟において次のことが判つた。

（1）不働態化寸る溫度範園においての夕研磨が可能で， かつ研磨には分解電堅以上に相當する電流密度が必要であ ろ.

（2）溶解量は淔流を用いた場合より中多い

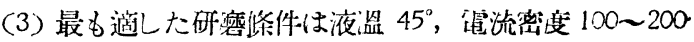
$\mathrm{A} / \mathrm{dm}^{2}$ 程度である.

(4) pitting 防止のため $1.5 \mathrm{~g} / \mathrm{L}$ 程度の鐵イオンが必要 である。

（5）被研磨面の凹部つ選擇溶出は淔流つ場合程著しくな (.

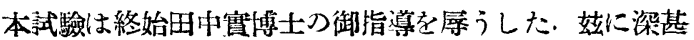
なる感謝の意を表する。 